\title{
Global, 'Glocal' and Local Dynamics in Calvary Temple: India's Fastest Growing Megachurch
}

\author{
Jonathan D. James
}

\section{1 \\ Introduction}

Satish Kumar, the founder and senior pastor of Calvary Temple in Andhra Pradesh, India is primarily known for building a gigantic church in $5^{2}$ days, thus emulating the feat of the Old Testament priest Nehemiah who built the walls of Jerusalem in $5^{2}$ days (Nehemiah 6:15). Calvary Temple was built in 2011 to seat 18,000 people (complete with overflow facilities); in 2018 it has close to 200,000 members who worship in four services in the Telugu language and one in English, all on Sunday. In addition to the church, Kumar has a Bible School, conference halls, and other state-of-the-art facilities at the 12-acre property in Hyderabad.

In this chapter, I describe how Calvary Temple (hereafter CT) was created, how it operates organisationally, and how the church undertakes its ministry in a nation that is not favourably disposed to Christianity. I also contemplate whether CT is navigating a new path, perhaps as a 'trailblazer' for the future of the Christian community in India.

Having acquired the status of a megachurch, a phenomenon that emerged in the latter half of the 2oth century in the West (especially in the USA) (Thumma, Travis and Bird 2005), CT's size is regarded as an indicator of success. But how did CT grow so big so quickly in a Hindu nation where there were and still are increasing tensions between Hindutva forces and minority religious groups? ${ }^{1}$ I use the theoretical underpinnings of Robertson (1995) to frame my proposition that CT is a product of both globalisation and glocalisation - the latter being the connection and interplay between the global megachurch movement and the local forces at work in contemporary Indian society.

In my research, I use both primary and secondary sources: primarily, I interviewed six senior Christian leaders in India who are familiar with CT and the

1 Hindutva literally means Hinduness and it is generally associated with the ideology that seeks to relate and define Indian culture with Hindu religious values. The current BJP Party is the main instigator of this ideology, which taken to its extreme would mean an 'India for Hindus only' policy and practice.

(C) JONATHAN D. JAMES, 2020 | DOI 10.1163/9789004412927_016

This is an open access chapter distributed under the terms of the CC BY-NC 4.o ficensefean D. James - 9789004412927 
church scene in India; ${ }^{2}$ and I analysed several of Kumar's preaching videos to get an idea of the thrust and philosophy of his ministry. Secondarily, I reviewed key texts and websites pertaining to CT and its senior pastor, Kumar.

I begin the chapter with a quick snapshot of the history of politics and Christianity in India, followed by background material on CT and its founder. I then outline the theoretical underpinnings of my study, followed by my analysis of CT from three standpoints: global, 'glocal' and local. I conclude with summative statements from my research and speculative questions about the future of CT.

Britain colonised India for 250 years. Towards the end of this rule - from 19091935 the British categorised the Indian population into a general electorate of Hindus and electorates representing Dalits (the outcastes) and those from the minority religions (Christians, Muslims and Sikhs) (Sharma and Varshney 2014). Dalit Christians were included in the Christian electorate.

In 1935, the famous Dalit leader B.R. Ambedkar urged Dalits to abandon Hinduism for a more impartial faith. ${ }^{4}$ At the same time, the noted nationalist leader Mahatma Gandhi strongly criticised the various Christian efforts to convert the Dalits. He, however, proclaimed that Hinduism should be reformed so that the status of untouchability of the Dalits was negated (Harper 2000). In 1936, Christian Dalits were not entitled to receive government benefits (Webster 1992). And between the years 1936 and 1946, many states in northern India introduced anti-conversion laws (Kim 2003). Following independence from the British in 1948, debates raged on the issue of conversion. The main party in power - Indian National Congress (INC) was sympathetic to the minority religions - whereas the Bharatiya Janata Party (BJP) upheld a Hindu nationalist agenda. In 1950, the INC ratified the Constitution to ensure rights for

2 I interviewed leaders of three mainline churches, a leader of an interdenominational Christian organisation, a Christian social justice activist and a retired missionary who served in India.

3 I am grateful to the Pew Research Centre for the information provided in their website which enabled me to fill in the gaps for this section: http://www.pewforum.org/2006/10/05/ historical-overview-of-pentecostalism-in-india/.

4 Dalit literally means 'trampled upon' and refers to people in low castes, who are treated as 'untouchables' in India. Dalits are a mixed population, living all over the country, speaking a variety of languages and practising different religions. Approximately two-thirds of India's Christian population, are Dalits. In many states, Dalits are not allowed to walk in upper-caste areas. In some restaurants, Dalits may be required to squat on the floor (rather than sit on chairs) and eat from separate dishes. 
religious propagation. In the same year, a presidential order excluded non-Hindu Dalits from legislative, educational and professional positions, reserving these for Hindu Dalits. In 1956 and 1990 amendments were made to allow Sikh and Buddhist Dalits to be eligible for the same positions, but Christian Dalits were still exempted (Freston 2001).

In the 196os, the growth of Christianity in north-eastern and central India generated tension among some Hindus. In 1964, the World Hindu Council was established in part to counter Christian conversions among tribal groups (Katju 2003). The state assemblies of Tamil Nadu and Gujarat passed anticonversion laws in 2002 and 2003 respectively (Ram 2002). After a series of victories in several state elections and in the national elections, in 1996, the Bharatiya Janata Party (BJP) became the largest party in parliament. However, due to its lack of representation in Parliament's lower house, the вPJ government was in power for only 13 days. ${ }^{5}$

At the 1998 general election, the BJP-led coalition, known as the National Democratic Alliance (NDA), formed a government under Prime Minister Vajpayee but this coalition only lasted for one year. Then, after fresh elections, BJP lasted for a full term in office - the first non-Congress government to do so in India's history. During the 2004 elections, Sonia Gandhi, the then INC leader, a Catholic, campaigned against the maltreatment of Christians and Muslims under the BJP (Waldman 2004). The INC won the elections and Manmohan Singh a Sikh became prime minister. He undertook the responsibility to curb violence against Christians (Waldman 2004). In the same year, State of Tamil Nadu's chief minister, J. Jayalalithaa, repealed the state's anti-conversion law after her party, which formed a coalition with the BJP, lost all its seats in the national parliamentary elections (Lisa 2005). After 10 years of rule by the INC, the Bharatiya Janata Party (BJP) was elected into power in 2014 even though this meant the possible rise of Hindu Nationalist politics and violence against Christians and other minorities.

\section{Calvary Temple and Its Founder}

Satish Kumar was born in 1971 within a poor family in Hyderabad, India. Unfortunately, Kumar took to the streets at a young age and fell in with bad company.

5 A new party - The United Front party consisting of both non-Congress and non-BJP members was formed and secured support from the 332 members out of the 545 seats in Parliament, with H.D. Deve Gowda being installed as the Prime Minister. Parliament produced three Prime Ministers between 1996-1997 and forced the country back to the polls in 1998. 
His parents were greatly concerned about his well-being and his future. One day, Kumar heard a street preacher say that Jesus could change people. Kumar contemplated that if Jesus could change him - that would be a miracle and it would attest to the reality of Jesus. So, he went forward in the 'altar call' and committed his life to Jesus Christ (Calvary Temple Website A; YouTube Kumar 2018).

Kumar joined a church and participated in various Christian activities, such as doing manual work for the conferences sponsored by the Indian Evangelical Mission (IEM) - a well-known indigenous, evangelical missionary organisation. At the age of 21, Kumar started a vibrant youth fellowship group - the Calvary Youth Mission (Field notes 2018).

In 1995, Kumar felt he received a call from God to build a very large church, but nothing significant materialised for the next 10 years (Brown 2015). Kumar also had a television ministry that he could not sustain financially. He therefore travelled to the USA to raise funds, but he was not successful in getting any appreciable and ongoing donations (NRB 2018). In 2005, Kumar started CT with 25 members. By 2015, the church grew to 130,00o members, adding 60,000 in the last three years alone (Brown 2015). The 2018 membership at CT stands at 195,00o people (Calvary Temple Website A).

Despite opposition from various groups, including agencies of the local government, Kumar urged his team of followers to build the afore-mentioned megachurch in a record time. One of my interview respondents, a Christian leader from a local church revealed that it was remarkable that Kumar himself participated in the building project, doing manual and other related work at times even in the rain (Field notes 2018). This involvement was a vital ingredient for the success of the building programme at CT (Field notes 2018). It should be noted that CT is a non-denominational, evangelical church, not associated with the classical Pentecostal or the recent neo-Pentecostal movement as are most megachurches in India and worldwide. Anderson (2004: 123) revealed that "at least a third" of Asia's Christian population is now Pentecostal or neo-Pentecostal, and that this figure is "steadily rising".

Globalisation is defined variously: it is seen largely in political and economic terms as the movement of capitalism across the world, creating interdependent relationships (Ruggie 1998; Scholte 2000). Globalisation has made the world more interconnected, where the political, social, and economic events in one nation influence individuals and nations elsewhere (McCorquodale 
and Fairbrother 1999). In a global world, Kinnvall (2004: 742) alluded, individuals may be more inclined to use religion as the integrating point in their lives because people "search for constant time and space-bounded identities".

In his analysis of globalisation, sociologist Robertson (1995) invoked the subconcept of 'glocalisation' as the "simultaneous occurrence of both universalizing and particularizing tendencies" in contemporary systems (Blatter 2013: para 1). Robertson (1995) argued that globalisation on its own was an over inflated reality and that the boundaries between the local and the global were connected. And Robertson conceived the local as a key facet of globalisation. Therefore, while acknowledging that global cultural links may be strong throughout the world, Robertson predicted that globalisation would not result in the formation of a united human culture (Robertson 1995). He argued that glocalisation has the impact of channelling global influences according to the local culture's needs, structure and taste. Thus, the local processes meld with global processes and vice versa. In short, the term glocalisation means that trends of homogenisation and heterogenisation coexist throughout the modern age. Furthermore, glocalisation means that it is local culture which assigns meaning to global influences, and that the two are therefore interdependent and enable each other (Cultural Reader 2012 para 4).

In a similar vein to Robertson (1995), Hexham and Poewe (1997) took this concept into religion and argued that even though Pentecostal Christianity is a global faith with a global framework, it is grounded in a variety of local forms and logistics. In Asia, there is a long-held perception of Christians as 'foreign', 'anti-national' and 'neo-colonial', even more so than in Africa or Latin America (Jenkins 2002: 175-177, 182-185). Hence, the growth of Pentecostalism, especially through megachurches in Asia, must be understood in the context of these negative sentiments.

Considering the above, I assert that Christianity in India is more likely to see real growth and be sustained if the global Christian elements and fused with local components of language, culture, theology and the like (James 2010).

Key Elements of Calvary Temple

I examine CT from three strategic standpoints: global, glocal and local. The global features refer to attributes that are linked to the fraternity of megachurches worldwide, especially in relation to the theological construct of Pentecostalism and neo-Pentecostalism. The glocal features refer to global aspects that have been fused with local issues to reflect unique sociocultural adaptations. The local refers to the features that have resisted global constructs (not become glocal) and remained unique to the Indian Christian context. 


\subsection{Global}

As stated above, the term megachurch was popularised, especially in the USA in the early 1980s (Schaller 1980). Scholarship undertaken in the late 1990s and in early 2000 equated the term 'mega' with size - the number of attendees and, by extension, the facilities to accommodate the large number in the congregations (Thumma and Travis 2007).

Megachurches in India certainly have large and relatively magnificent buildings. Seen in the context of India's demographic, where poverty is rampant, these buildings appear luxurious. ${ }^{6}$ For example, the Mark Buntain Memorial Assembly of God Church in Kolkata is built as a large theatre where the seats are cushioned (Sungjemmeren 2011). CT and two other megachurches located in Bangalore - have chairs or pews for all who come to the worship service unlike some churches in India, where the congregation sits on the floor according to gender, age, caste, or class ${ }^{7}$ (Sungjemmeren 2011). CT's auditorium is fully air-conditioned - therefore, this is a novelty for churches in India.

What is emphasised in CT's website through the promotional videos on YouTube and the interviews of Pastor Kumar, is the fact that the church was built in $5^{2}$ days - alluding to the similarity between Kumar and Nehemiah, the Old Testament priest:

Is it possible to build a church with a capacity of nearly 18 ,ooo in $5^{2}$ days? This is a million-dollar question. Even many godly people thought that Bro. Satish Kumar made a wrong decision in announcing that the church will be built in $5^{2}$ days. If the Church was not built in $5^{2}$ days then whatever name he had earned during these years will be wiped out. But God was so good to Bro. Satish Kumar and his word. Though many problems and challenges were encountered during construction yet God kept HIS promise and helped build the church in $5^{2}$ days. All the church members entered the new sanctuary on 1st January 2013.... celebrated God's victory and saw the work of His hand. Glory be to God!

Calvary Temple website A, para 14

A book entitled 52 Day Miracle - written by USA author Peter Spencer, with a forward by bestselling author and US megachurch leader, Rick Warren - chronicles

6 According to World Bank data in 2011, the world had 872.3 million people living below the new poverty line, of whom 179.6 million people live in India. Therefore, India with 17.5 per cent of the total world's population, had 20.6 per cent share of the world's poorest in 2011 (Donnan 2014).

7 The other two churches are: Full Gospel AoG Church - a megachurch started by an Indian theological graduate in the 1980 s and Bethel AoG Church which was started by Bible college teachers as a house church in the 1950 . 
the amazing miracle of building CT in a short span of time (52DayMiracle.com). The book and CT's focus highlight the perception of the miraculous nature of the church. Other parts of the CT website refer to the church as ".... the biggest church in India" and "the fastest growing church in the world" (Calvary website B). Dawn (1999: 29) reflected that such an emphasis on measurement is revealed by the "huge push for worship practices to be changed to attract large numbers". However, Dawn (1999:52) also warned that when size is the main objective "....the danger to the church is enormous and, strangely, often not obvious.... Quality suffers when the main concern is quantity". The emphasis on size can be understood in relation to critical studies on American businesses and entities based on Disneyfication - a reference to the world-famous theme park, Disneyland. Rojek (1993) argued that the moral and political culture of entities that take on the Disney leisure industry act as a "mouthpiece of the American way" (Lyon 2000: 4). Furthermore, Rojek (1993) maintained that Disneyfication encourages people to relate to spectacle and passive consumption. Like most megachurches around the world, CT attracts the younger demographic - almost 7o percent of the congregation are between the ages of 25 and 45 (Reddy 2015). The spectacle and passivity of the above-mentioned theories mayrelate with theyounger demographic at CT who share more readily with the global and Western culture. ${ }^{8}$

Perhaps surprisingly, Kumar does not share Pentecostal or neo-Pentecostal beliefs unlike many megachurch pastors in India and the rest of the world. However, CT is consistent with the trend for most megachurches to downplay their denominational links (Thumma 1996). CT's website describes the church as 'evangelical' and 'non-denominational' (Calvary website B). However, $\mathrm{Ku}$ mar has identified with the Yoido Assembly of God (AoG) church in Seoul Korea which is a Pentecostal church that is considered the largest church in the world with 800,00o members. Kumar has been a guest preacher at Yoido AoG several times. And Kumar has also been interviewed over TV networks owned and operated by neo-Pentecostal groups such as Trinity Broadcasting Network (TBN) and Christian Broadcasting Network (CBN). Furthermore, he is featured regularly in Charisma, a neo-Pentecostal US publication. ${ }^{9}$

8 Mark Chaves argues that spectacle is part of the megachurch movement in "All Creatures Great and Small: Megachurches in Context," Review of Religious Research (2006). Jeanne Kilde also raises this perspective with the penetrating question, "Is Christianity, at some level, always about performance and spectacle?" See - When Church Became Theatre: The Transformation of Evangelical Architecture and Worship in Nineteenth-Century America (Oxford, 2005).

9 In Transnational Religious Movements: Faith's Flows (Sage, 2017), I argue that transnational religious groups aspire to go to the West and especially to the USA to start branches or minister 
Kumar claimed that he does not resort to 'signs and wonders' in attracting people to his church (Day Star 52 Day Miracle 2018). People come to the church, according to Kumar, for the Word of God (твN YouTube). However, Spencer (Day Star 52 Day Miracle, 2018), attested to healings, miracles and supernatural phenomena when he visited CT. Signs, wonders and healings are part of the teachings and manifestations of Pentecostal and neo-Pentecostal movements across the world. The CT motto reflected in the changing banner on the website says: "Be First, Be Best or Be Different" (Calvary website B). The church motto clearly resembles the prosperity, success and wellness gospel of the global Pentecostal movement. The motto appeals to the suburban, middleclass people (presumably the younger demographic) who would hear similar catch phrases from their workplaces and companies advertised on TV, radio and social media.

In a sermon given in 2016 (YouTube Kumar 2018), Kumar alluded to the fact that to fail examinations at school and college is a condition that brings shame to families and people in the community. Presumably, this reference to shame would gain traction in India where the culture puts a very high premium on education and success in academia. Kumar's comment is an indirect way of espousing the prosperity gospel, an offshoot of Pentecostal teaching. Kumar's comment also displays a lack of sensitivity to the number of suicides by youth in India after failing their examinations. ${ }^{10}$

CT follows the centripetal perspective of Christian ministry (with its emphasis on gathering adherents to the church), rather than the centrifugal perspective wherein Christians are encouraged in the New Testament to "go into all the world and make disciples...." (Matthew 28: 18-19; Clowney 1995; Miller 1996). Missiologists call CT's philosophy the 'attractional church' philosophy where the focus is on people coming to the church as opposed to the 'missional church' philosophy where the focus lies in going out to the world to bring disciples into the faith:

Attractional church is a come-to-us mentality in which church revolves around the Sunday meeting.... This is the missiology of the Old Testament. Israel was to so live under God's reign expressed through his law that the nations would come to find out about Israel's God (Deuteronomy

to the diaspora population there. In this case, CT's leader seems to travel to the West more for the purposes of networking, publicity and political activism.

10 India has one of the world's highest suicide rates for youth aged 15 to 29 and student suicides are frequent enough that celebrities and policy makers have started to call for action (Saha 2017). 
4: $5^{-8)}$ )... When we come to the church in the New Testament, people often assume a switch of direction from 'drawing in' to 'going out'.... CHESTER 2008: para 6-8

Like many Pentecostal megachurches, CT depends heavily on its senior pastor. For example, the congregation looks to the senior pastor for all decisions. The preaching, charisma and strong leadership of the senior pastor all perpetuate the senior pastor's power. When interviewed, one of the respondents asserted: "Kumar is not only the leader, he is the 'brand' of the church and without him the church will not move forward.... he is given celebrity status - he wears 5 different sets of clothing for each of the 5 services on Sunday" (Field notes 2018). Another leader extended this view to Kumar's family: “Kumar's wife and his brother are also key decision-makers and power sources at Calvary" (Field notes 2018). Kumar's brother, a convert from the Hindu faith has quite a high profile in the ministry of the church (Reddy 2015). Kumar's wife is currently the Sunday School Superintendent replacing the former superintendent because of the latter's disagreement with the senior pastor (Field notes 2018). Kumar's and his wife's birthdays are mega events that are celebrated in the church. As a rule, no other birthdays are celebrated or acknowledged at CT (Field notes 2018).

Another interview respondent bemoaned the fact that whereas there is a ministry team led by the senior pastor there is no governing forum where decisions can be considered, drawing the expertise of the leadership team (Field notes 2018). This respondent explained why Kumar is the acknowledged, dominant leader of the congregation:

He [Kumar] started the church from scratch. He had the vision and he built the church in $5^{2}$ days. This action therefore qualifies him to be the sole leader, decision maker and final arbiter of the church. The subtext of the promotions and public relations messages imply that the miraculous emergence of the leader and his ability to grow a church constitutes spiritual leadership and therefore demands the full allegiance of all the members....

Field notes 2018

The worldwide fraternity of megachurches focus on training volunteer leaders for their various church ministries (James 2010; Reddy 2015). Short-term courses enable church members to serve the church in a multiplicity of areas, including leading cell groups - a key component of CT's ministry. Other volunteers are used in ministries ranging from music to providing car parking 
assistance and to ministries for youth and senior citizens. Besides the full-time paid employees, called Calvary Army, Kumar has two types of volunteers Calvary Soldiers, who are semi-employed volunteers and Calvary Amateurs unpaid enthusiasts (Reddy 2015). In this way the whole congregation has the potential of being transformed into voluntary semi-paid or unpaid 'co-workers' (Reddy 2015: 159).

Professionalism, the use of technology, and mediatisation are yet other features of CT in line with the global megachurch movement. The worship services at CT reflect a Western bias with the use of guitars, drums and wide-screen projection facilities. The worship segment is performance-oriented; that is, the focus is on the worship team and their professional singing and playing. The congregational singing cannot be heard because it is overpowered by the sound of the accompanying music and the singers in the worship team (Field notes 2018).

Remarkably, all attendees have electronic cards that they swipe before entering the worship centre. The card records attendance and enables tithing to be given efficiently. Every member of CT gets a swipe card and anyone can become a member on their first visit with a short declaration of their intention to become a member. On the spot membership is made easier because most first-time visitors are already familiar with Kumar and CT through his nationwide television ministry (Brown 2015).

Kumar's messages air on 300 TV channels each month in several Indian languages (Brown 2015). It is estimated that the more than 5,000 new visitors come to CT each week because of this media exposure, and many of the newcomers become committed church members (Brown 2015). Kumar's TV reach is estimated to be 10 million viewers (твN YouTube).

Like most megachurches, CT has a user-friendly website, a Facebook presence, and a YouTube channel which extend the church's scope. However, the most intriguing and noteworthy aspect of CT's global dimension is its growing transnational political activism. Kumar met with the USA Vice President Mike Pence in Washington D.C. in February 2018 while attending the National Religious Broadcasters Convention - where Kumar was their keynote speaker (NRB website 2018). The meeting Kumar had with Pence was considered major news at CT, and the Church website used this meeting to bolster Kumar's standing in the international scene. The talk with Pence was reported as a discussion about religious freedom - an obvious reference to the current Indian government's tardiness in handling the issue of the persecution of Christians in India by Hindu fundamentalist groups (N RB website 2018). Thus, Kumar has now been attributed with opening a global political platform to champion the 
rights of the 30 million Christians in India. ${ }^{11}$ Whether this engagement in the global field will be significant in advancing the cause of religious justice remains to be seen. But it certainly has the potential for both positive and negative outcomes for the Christian community in India.

Kumar's latest goal is to build another large church - a stadium-sized church edifice that will seat 6o,ooo people in another part of Andhra Pradesh - making it the largest church in the world (Calvary Temple website C). Clearly, Kumar's aspiration knows no bounds.

\section{2 $\quad$ Glocal}

At CT several innovations and cultural adaptations have evolved. The large buildings in the 12-acre property were built despite strenuous opposition from Hindu-inspired groups and local government agencies (Field notes 2018). In building CT, Kumar has successfully created an alternative space and imbued Christians with a sense of belonging. As mentioned above, CT provides seating for everyone, devoid of bias according to caste or class. Thus, the minority status of Christians in India is forgotten by worshippers when they gather at CT.

At CT, charity and meeting physical needs is a major component of the church ministry. Because of the electronic cards issued to all members, if anyone misses a service, they receive a telephone call the next day from a staff member, enquiring about their wellbeing and asking if prayer is needed (Field notes 2018). Brown (2015) explained this practice: "While this may seem overbearing for many Christians in the West, it is very meaningful to the Indian believers" (Brown, 2015 para 15). Amazingly, every member of the church gets a birthday cake delivered to their door on their birthday, which means CT hand delivers (through their network of volunteers) as many as 4,00o birthday cakes a day (Brown 2015; Field notes 2018). In the context of abject poverty amongst many in the church, and the fact that their families cannot celebrate their birthdays, it's not unusual to see recipients cry when their cake arrives (Brown 2015). CT also provides about 10,00o meals every Sunday for poor members and subsidises $5^{\circ}$ percent of the cost of all medical prescriptions (Brown 2015).

The preaching and worship at CT also show glocal elements. There are five two-hour services every Sunday and Kumar preaches for 60-70 minutes at each service (Brown 2015). It is interesting to note that the first Sunday service commences at $6.00 \mathrm{am}$; and the last service concludes at $8.00 \mathrm{pm}$. Kumar also gives a 30-minute teaching session to 1,200 key church workers before one of

11 The 2011 Indian Census shows 2.3 per cent of the population as being Christians. Some Christian leaders think this figure is understated. See: http://censusindia.gov.in/Census_ And_You/religion.aspx. 
the late afternoon services (Brown 2015). As mentioned earlier, Kumar is not theologically linked with the Pentecostal or neo-Pentecostal movement, so his sermons are biblically-based and free of calls to receive the second blessing, the gift of tongues and the like. Instead: “.... he [Kumar] does not mince words, calling out sin, calling for repentance, and pointing to the cross. His goal in all his messages is that Jesus be exalted" (Brown 2015: para 11-12). Kumar's preaching content and delivery style display more of a Baptist and evangelical theological orientation than that of the Pentecostal tradition.

The respondents I interviewed all agreed that Kumar is not the best preacher, but he gives clear, biblical and easy-to-understand sermons (Field notes 2018). CT's website, with links to the church's YouTube channel, describe Kumar's preaching this way:

He adopted his preaching method from Jesus Christ, i.e. preaching the word with illustrations and parables. This greatly helps people to understand the word and apply it to their daily lives. His spirit filled sermons have attracted hundreds and thousands of people to Calvary Temple....

Calvary Temple website A

From my observation, Kumar's use of stories, folk tales, anecdotes and illustrations in his preaching bears similarity to the Hebrew method of parables used by Jesus Christ, and it resembles the style and presentation of the Indian folk teacher:

Since, Indian folk religion exists primarily in oracy [oral-based using communication by word of mouth], the concept of time and space within the narrative becomes cyclical.... the stories oscillate between the past and the present.... therefore the congregation relates to the narrative and applies it to everyday life.... pastors entitle the themes of their messages as abundant life, successful life.... and victorious life... every message is instructional, promise-filled and relevant....

REDDY 2015: 155-156

In my content analysis of Kumar's sermons on YouTube, I noticed that 18 out of the 20 sermons had titles such as: How to live an extraordinary life, how to get value from life, and how to be free from a sinful life. Furthermore, my content analysis revealed that Kumar's preaching method is to reduce biblical truth to 'bite size' pieces. He gives his listeners gems of truth in the form of easy-to-understand biblical principles. For example, in response to the issue of 'How to live an extraordinary life' Kumar exhorted: "Be prayerful, be peaceful, 
be patient and be pure". And in a sermon, that resonated with the poor and marginalised titled: "There is hope for the useless and the hopeless", Kumar urged the congregation to take heart because, although the people of Israel were slaves for hundreds of years, they were eventually delivered by God's servant, Moses. Then, Kumar added: "Joseph was sold as a slave but he did not live as a slave". At this point, Kumar shared his own story of how at 12 years of age, he was thought to be useless by his family. He was engaged in smoking and gambling, all of which brought great shame to his family. But he was delivered (YouTube Kumar 2018).

Hence Kumar, like an Indian folk narrator applies the narrative of the bible to his own life and then, to the lives of the listeners, thereby connecting the past with the present and engaging with the congregation. Kumar's preaching method is not expository; he does not preach a passage of Scripture by explaining the language, history and context to draw out the meaning of the passage. Kumar's preaching method is topic based - on a single verse of Scripture or a short passage with a view to answering one of the issues outlined above. Considering the large number of worshippers in each service at CT, and the demographic of the congregation, Kumar's style of preaching is apt and effective.

As indicated above, the main thrust of CT is its worship services on Sunday. A large Sunday School ministry exists for young children and youth, but it seems that the Sunday School is considered more of an 'afterthought' - a convenient place for parents to leave their children with teachers while they attend worship in the main auditorium (Field notes 2018). There is no systematic curriculum for Sunday School, and not all the teachers are adequately equipped to handle the children of different ages (Field notes 2018). One of the interviewees explained: "It is a pity that Kumar has put so much emphasis on the worship services and the other ministries, but he has clearly neglected the ministry of the Sunday School" (Field notes 2018).

\section{$5 \cdot 3 \quad$ Local}

CT has several local characteristics that are typical to the Indian context. The Indian church has a spirituality that is quite different from her counterpart in the West. For example, there is no secular-sacred divide: "In Indian epistemology yoga and bhoga are used as synonyms for the sacred and the secular - that is, spirituality and worldly happiness" (Chaudhuri, n.d.). Hence, even television becomes sacred when it relays a Christian message (James 2010). This explains why the actual worship centre and the recognition of leaders' birthdays have such great spiritual significance.

Indian churches accept a literal interpretation of the Bible and furthermore, whereas Christians in the West have downplayed the supernatural, Indian Christians embrace the supernatural and pray fervently against the forces of 
spiritual darkness. When Kumar sensed the call of God to build CT in $5^{2}$ days, he relied on the verse in the Old Testament book of Nehemiah: ".... the Word gave me faith to repeat history...." (Daystar $5^{2}$ Day Miracle 2018). Thus, Kumar staked his life and reputation on the bible and the literal meaning of the promise given to Nehemiah. He also chose the nth of November - his birthday - as the starting day for the building programme for CT. This was the day that the foundation stone was laid. (Day Star $5^{2}$ Day Miracle, 2018).

There is a very strong emphasis on prayer and fasting as part of the discipline of the life of a Christian in Indian churches. Brown illustrates this at CT:

The congregation always put a strong emphasis on prayer and fasting, but when they were about to embark on their building project, Pastor Satish [Kumar] called for 40 days of prayer and fasting, with believers fasting and joining together in corporate prayer as much as they could.

The problem was that he called for this during the rainy season, a time when it is unbearably hot and unbearably wet. Yet night after night crowds of thousands gathered on the empty property to join for hours, sitting with their umbrellas up as Satish preached in the pouring rain (without an umbrella). It made for quite a sight (Brown 2015: paras 6-9).

After the first 40-day period of prayer and fasting, Kumar called for another 40 days of prayer and fasting, and when that ended, he called for 40 days more - adding to a total of 120 consecutive days of corporate prayer and fasting (Brown, 2015).

Kumar preaches mostly in the Telugu language - the main language spoken in the State of Andhra Pradesh. All the services are in Telugu except one at 6.oo $\mathrm{pm}$ that is in English. Telugu worship songs are sung in the services. Although Kumar is a good communicator in the English language, when he preaches in Telugu, he does so with greater fluency and grace.

Kumar has claimed that the church was fully funded by local giving (Daystar TV YouTube 2017). However, Spencer (Daystar TV YouTube 2017), in the same video, alluded to the fact that when he met Kumar in the USA, Spencer promised to financially support Kumar before the building project was completed. We are not told whether funds eventually came from the USA or other foreign countries.

When Christianity came to India through Saint Thomas (as alluded to in rich historical traditions), ${ }^{12}$ Thomas had a positive response in gospel witness

12 The following works are used to support this tradition of St. Thomas' ministry in India: Mingana, A. The Early Spread of Christianity in India (Manchester: Manchester University Press, 1926), 15-16. Also, Acts of Thomas 1 (c. AD 200-220); Teachings of the Apostles 3, (3rd. 
from the cultured and wealthy Indians (Firth 1961; Philip 1950). However, with the entry of British and American missionaries in the 18th and 19th centuries, the Christian message was redirected toward the lower classes (Firth 1961; Philip 1950; Wolpert 1991). Christians - mostly from the lower rungs of society are generally treated as second class citizens. Hence, the positive aspect of CT is that Kumar has managed to make the church a place where the various castes and classes can mingle without sociocultural and economic division.

Notwithstanding, CT and several other megachurches in India have tried to resolve the delicate issue of Christianity and sociopolitical acceptance. Baptism and communion are two sacraments that the Church worldwide has practised unequivocally. In India, baptism is a contentious issue because most Christian converts are from what is referred to as Scheduled Castes (SC). When a convert from a SC is baptised, he or she then goes on record as an Indian Christian. However, Indian Christians from SCs are treated as members of Backward Class (BC) and denied government benefits. Only Hindu SCs are granted government benefits. ${ }^{13}$ To deal with this matter, the sacrament of baptism is oftentimes bypassed at CT and other megachurches in India (Reddy 2015). Hence the Indian Christians from SCs enjoy membership at CT as well as benefits in society.

Whereas the various castes and classes can mingle, CT upholds gender segregation in the seating arrangement at the worship services - women and men are seated separately. This is in keeping with most denominational and nondenominational churches in the nation. At CT, Sunday School is for all children and youth but there are separate seating sections for boys and girls. At present, only male teachers can minister to the Sunday School children, to avoid male and female teachers fraternising (Field notes 2018). At one time all the teachers were women; however, that changed recently without much explanation. (Field notes 2018).

CT upholds the notion of the church as a family. The church caters for the whole family and there are activities beyond Sunday for various members. However, CT goes a step further than most churches regarding the issue of property ownership of its members: members must declare their assets and

century); Hippolytus on the Twelve (c. 3rd. cent.); Origen, Commentary on Genesis, vol. 3 (d. c. 254); Clementine Recognitions 9.29 (c AD 350); St. Gregory of Nazianzen, Oration 33.11 (c. AD 325-390).

13 The 1950 legislation listed Hindu Dalits as a "Scheduled Caste", which made them eligible for free education with a quota of jobs made available to them in the government and seats in state legislatures - as a way of improving their status. The same privileges were extended to Sikh Dalits in 1956, and to Buddhist Dalits in 1990. However, similar preferences were not given to the Muslim and Christian Dalits. 
make agreements in the presence of the church leaders as to how family property and assets will be divided (Reddy 2015). Kumar believes that this prevents family conflicts and avoids unnecessary litigation cases in courts (Reddy 2015). This is another instance of the infusion of Indian collectivistic culture in CT as opposed to the situation in Western churches where individualism prevails.

\section{Discussion}

CT is characterised by its size and the amazing contribution of its senior pastor - Satish Kumar. There is no record of Kumar's training to become a pastor - except that he was ordained by an unnamed UK church and that he received an honorary doctorate from a University in the USA. Kumar is the acknowledged leader because of his stupendous accomplishment in building the church in $5^{2}$ days - not because of his training or experience in ministry. Likewise, the church is considered outstanding not because of what it teaches but because of how it was conceived. And Kumar's goal to embark upon yet another building project - to build the largest church edifice in the world - is fascinating and yet disturbing. His innovative vision is exciting, but his motivation to have the biggest and the largest church in the world raises 'red flags'.

The focus of CT is based on the 'attractional church' model. This is the Old Testament approach to ministry. CT does not follow the 'missional church' model based on the New Testament approach of going into the world. The 'attractional model' seeks more and more people to come to the church and this would prove to be unsustainable in the long run as it would require bigger facilities and larger infrastructures.

The pastoral care, the feeding of people, and, subsidising the cost of medicines in a nation where many cannot afford any kind of health care is commendable. However, such a preponderance of welfare prompts the question: Are people coming to CT for their devotion to Jesus Christ, or are they merely 'rice Christians', as in the colonial days of missionary work when some conversions were induced by handouts from missionaries.

The focus on lay people participating in the church seems to be working well. It is an empowering exercise when people of various castes, classes and age groups are brought together for a common purpose and for the mission of the church. The division of the church into various cell groups is noteworthy. A sensitive cell group can be effective, even in a religiously-plural nation when adherents have a spiritual base, are needy and open for divine help and guidance. 
Arguably, CT has created a counter-cultural community in urban Andhra Pradesh. The church has by its size and power provided a new sense of belonging to its members, but more importantly it has also established a new power base and a buffer for Christians from the Hindu-based national government.

CT's transnational political activism is something to watch closely. Kumar's links with USA's Vice President, and the ongoing discussions on Hindu India's issues pertaining to religious freedom may have interesting ramifications in the coming days. The Church's focus on Telugu-based services (sermons and music) and Kumar's preaching style - based on the Indian folk narrator tradition - are key factors in Kumar's engagement with his listeners, thereby ensuring the success of the widespread ministry of the church. However, the control and governance of the church leadership are significant issues for the church to consider as it endeavours to move forward.

My analysis of CT according to global, glocal and local indicators reveal that global factors seem to take prominence over the other issues. CT conforms to the ethos and logistics of the global megachurch movement especially in its obsession with size, church attendance and seating arrangements. Furthermore, it associates with other megachurches in Asia and the world. Nevertheless, the glocal and local aspects are strong and indicate that whereas CT is sustained mainly by its association with aspects connected with the global megachurch movement, the glocal and local factors are weighty enough and give CT its foundation and grounding as a church in India's Hindu-oriented society.

In this chapter, I have situated CT's growth and ministry in the context of the cultural and religious landscape of India. The growth of CT is amazing considering the Indian government's chequered history with the Christian church. CT is India's largest megachurch and it is poised to become by far the largest church facility in the world. The church is clearly part of the global megachurch movement but it still maintains glocal and local elements that ensure a promising future. The chapter indicates that the global aspects of the megachurch movement are being assimilated within CT's Indian identity, tradition and aspirations. However, given the current trajectory of CT's alignment with conservative Christian politicians in the USA, the global elements may strengthen and upset this balance.

The Rev Satish Kumar is not known for his oratorical skills (although his preaching style which resembles the Indian folk narrator is effective for India), but his visionary leadership and organisational acumen are impressive. CT has 
created an alternative space for marginalised and disenfranchised Christians especially those from the lower echelons of Indian society. Kumar has managed to imbue Indian Christians in his church with the strength of collective identity.

Nevertheless, from an organisational point of view, there are some doubts surrounding CT: What will happen after Kumar leaves the scene? Also, will the church and its future projects be sustainable given the 'larger than life' goals of the current senior pastor?

But perhaps the most critical question is: Does CT exceed its remit as a Christian church? It is a socio-political entity boldly declaring to Indian Christians-at-large that there is potential for the disruption of the political status quo because Kumar has negotiated links with powerful Christian politicians in the USA, including the current Vice President, Mike Pence. From this larger, macro viewpoint two further questions emerge: Does CT reflect the changing fortunes of Christianity in India? Will the global aspect of CT become more pronounced as the church becomes the mouthpiece for the articulation of religious freedom in India?

\section{References}

Anderson, A. 2004. An Introduction to Pentecostalism: Global Charismatic Christianity. Cambridge: Cambridge University Press.

Blatter, J. 2013. "Glocalization”. Encyclopaedia Britannica. Retrieved 21 April 2017 from https://www.britannica.com/topic/glocalization.

Brown,M.2015. "7 Lessons From the World's Fastest Growing Congregation”. The Christian Post. 13 December 2015. Retrieved 15 January 2018 from https://www.christianpost .com/news/7-lessons-from-the-worlds-fastest-growing-congregation-152310/.

Calvary Temple website A. Retrieved 10 February 2018 from https://www.youtube.com/ watch? $=\mathrm{eVVhL}_{5} \mathrm{UG}_{7} \mathrm{YY}$.

Calvary Temple website B. Retrieved 11 February 2018 from http://www.calvarytemple .in/.

Calvary Temple website C. Retrieved 11 February 2018 from http://www.calvarytemple .in/about/.

Chaudhuri, N. n.d. "Intertwining the Sacred and the Secular". Retrieved 18 May 2018 from http://www.indranathchoudhuri.com/Articles\%2onew\%2onew/2/Intertwining

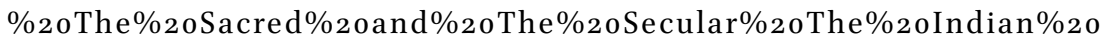
Approach\%2oto\%2ocreating\%20a\%2oNew\%2oHumanity.pdf.

Chaves, M. 2005. "All Creatures Great and Small: Megachurches in Context". Review of Religious Research. 47:4, 329-346. 
Chester, T. 2008. "Attractional Church versus missional Church". Tim Chester. Retrieved 20 May 2018 from https:/timchester.wordpress.com/2008/og/21/attractional -church-verses-missional-church/.

Clowney, E. 1995. The Church: Contours of Christian Theology. Downers Grove: InterVarsity Press.

Cultural Reader Website, 2012. “Roland Robertson's Concept of Glocalization”. 10 May 2012. Retrieved 1 March 2018 from http://culturalstudiesnow.blogspot.com/2012/05/ roland-robertsons-concept-of.html.

Dawn, M. 1999. Reaching Out Without Dumbing Down. Michigan: William B. Eardmans Publishing.

Day Star TV YouTube. 2017. Retrieved 18 February 2018 from https://www.youtube .com/watch?v= $\mathrm{U}_{75} \mathrm{~S}_{2} \mathrm{~S}_{72} \mathrm{Hsw}$.

Day Star $5^{2}$ Day Miracle (Kumar and Spencer) 2018. Retrieved on 5 May 2018 from https://www.youtube.com/watch?v=tVG75avgsNo.

Donnan, S. 2014. "World Bank eyes biggest global poverty line increase in decades" The Financial Times 9 May 2014.

Freston, P. 2001. Evangelicals and Politics in Asia, Africa and Latin America. Cambridge: Cambridge University Press.

Firth, C. 1961. An Introduction to Indian Christian Church History. Chennai: CLS Press. Harper, S. 2000 In the Shadow of the Mahatma: Bishop V.S. Azariah and the Travails of Christianity in British India. Studies in the History of Christian Missions. Grand Rapids, USA: William B. Eerdmans.

Hexam, I. and Poewe, K. 1997. New Religions as Global Cultures: Making the Human Sacred. Boulder: Westview Press.

James, J.D. 2010. McDonaldisation, Masala McGospel and Om Economics: Televangelism in Contemporary India. Washington D.C. \& New Delhi: Sage.

James, J.D. 2017. Transnational Religious Movements: Faith's Flows. Thousand Oaks and New Delhi: Sage.

Jenkins, P. 2002. The Next Christendom: The Rise of Global Christianity. New York: Oxford University Press.

Katju, M. 2003. Vishva Hindu Parishad and Indian Politics. Hyderabad: Orient Longman.

Kilde, J. 2005. When Church Became Theatre: The Transformation of Evangelical Architecture and Worship in Nineteenth-century America. New York: Oxford University Press.

Kim, S. 2003. In Search of Identity: Debates on Religious Conversion in India. Oxford: Oxford University Press.

Kinnvall, C. 2004. "Globalization and Religious Nationalism: Self Identity, and the Search for Ontological Security". Political Psychology. 25:5, 741-767. 
Lisa, A. 2005. "Government Announces Anti Conversion Law Not in Force..." Christian Today 24 May 2005. Retrieved 18 May 2018 from https://www.indiatoday.in/ magazine/states/story/20021118-jayalalithaas-anti-conversion-law-causes-political -polarisation-in-tamil-nadu-794296-2002-11-18.

Lyon, D. 2000. Jesus In Disneyland: Religion in Postmodern Times. Cambridge: Polity Press.

McCorquodale, R. and Fairbrother, R. 1999. "Globalization and Human Rights" Human Rights Quarterly. 21:3, 735-766.

Miller, P. 1996. “Editorial: Whither the Church?” Theology Today. 52:4, 445-448.

NRB website. 2018. Retrieved 11 March 2018 from http://nrb.org/news-room/articles/ft/ vice-president-pence-hosts-nrb-members-white-house/.

Pew Research Center. “Overview:Pentecostalism in Asia”. Pew Research Center. Retrieved March 2018 from http://www.pewforum.org/2006/10/05/overview-pentecostalism -in-asia/.

Philip, E. 1950. The Indian Church of St. Thomas. Nagercoil: LMS Press.

Ram, A. 2002. "Jayalalithaa's Anti-Conversion Law". India Today. November 112002. Retrieved 11 May 2018 from https://www.indiatoday.in/magazine/states/story/ 20021118-jayalalithaas-anti-conversion-law-causes-political-polarisation-in-tamilnadu-794296-2002-11-18.

Reddy, S. 2015."Nurturing Globalized Faith Seekers: Mega Churches In Andhra Pradesh". In Ed. James, J.D. A Moving Faith: Mega Churches Go South. New Delhi and Los Angeles: Sage.

Robertson, R. 1995. "Glocalization: time-space and homogeneity-heterogeneity". In Eds. Featherstone, M. et al. Global Modernities. London: Sage.

Rojek, C. 1993. "Disney Culture”. Leisure Studies. 12:2, 121-135.

Ruggie, G. 1998. Constructing the World Polity: Essays on International Institutionalization. London and New York: Routledge.

Saha, D. 2017. "Every hour, one Student commits suicide in India". Hindustan Times. Retrieved 20 June 2018 from https://www.hindustantimes.com/health-and-fitness/ every-hour-one-student-commits-suicide-in-india/story-7UFFhSs6hiHNgr NO6oFZ2 2 .html.

Scholte, J. 200o. Globalization: A Critical Introduction. Basingstoke: Macmillan.

Schaller, L. 1980. The Multiple staff and the larger Church. Nashville: Abingdon.

Sharma, R. \& Varshney, N. 2014. "History of Separate Electoral System in India" LegalHeritage. Retrieved 20 March 2018 from https:/legalheritage.wordpress.com/2014/ 04/03/history-of-separate-electorate-system-in-india-by-dr-richa-sharma/.

Sungjemmeren, I. 2011. "Indian Megachurches Centripetal Mission". Lausanne World Pulse Archives. Retrieved 1 February 2017 from http://www.lausanneworldpulse .com/perspectives-php/136o/o1-2011. 
TBN YouTube. Retrieved 6 February 2018 from https://www.youtube.com/watch?v =GTeQ5_rnspM.

Thumma, S. 1996. The Kingdom, the Power and the Glory: Megachurches in Modern American Society. Emory University Dissertation. Retrieved 20 March 2018 from http://hirr.hartsem.edu/megachurch/dissertation.html.

Thumma, S., D. Travis and W. Bird. 2005. "Megachurches Today". Retrieved 17 December 2017 from http://hirr.hartsem.edu/megachurch/megachurches_research.html.

Thumma, S. and D. Travis. 2007. Beyond Megachurch Myths: What We Can Learn from America's Largest Churches. San Francisco, CA: Jossey-Bass.

Waldman, A. 2004. "In Huge Upset, Gandhi's Party Wins". The New York Times.13 May 2004. Retrieved 16 June 2018 from https:/www.nytimes.com/2004/05/13/inter national/asia/in-huge-upset-gandhis-party-wins-election-in-india.html.

Webster, J. 1992. The Dalit Christians: A History. New Delhi: ISPCK Publications.

Wolpert, S. 1991. India. Los Angeles: University of California Press.

YouTube A (Interview with Satish Kumar). Retrieved 10 March 2018 from https://www .youtube.com/watch?v=eVVhL5 $\mathrm{UG}_{7} \mathrm{tY}$.

YouTube B (There is Hope...sermon Kumar). Retrieved 12 March 2018 from https:// www.youtube.com/watch?v=_yKhilXgrQA.

YouTube C (Extraordinary Life...sermon Kumar). Retrieved 8 March 2018 from https:// www.youtube.com/watch?v=qP6Hi3hDd_g\&index=4\&list=RD8h6H6rgVxCY. 